SCJR 11, no. 1 (2016): 1-18

\title{
The Influence of Syriac Bible Commentaries on Judeo Arabic Exegesis as Demonstrated by Several Stories from the Book of Genesis
}

\author{
ARYE ZOREF \\ arye.zoref@mail.huji.ac.il \\ The Hebrew University of Jerusalem, Jerusalem 9190501
}

It has already been generally recognized that Syriac Bible commentaries influenced Judeo Arabic biblical exegesis, primarily thanks to Sarah Stroumsa's studies on the subject. Stroumsa has shown that Qirqisani, a Karaite Bible commentator of the tenth century CE, explicitly cited as one of his sources the Bible commentary of Daud b. Marwan al-Muqammis (a Jew who converted to Christianity and then converted back to Judaism), whose commentary was based on Syriac sources. ${ }^{1}$ Stroumsa also demonstrated the Syriac influence on R. Saadia Gaon's introductions to his biblical commentaries. ${ }^{2}$ However, so far there has been no detailed examination of the reception of the Christian Syriac commentaries in Judeo Arabic exegesis. We have no explanation regarding the way in which Judeo Arabic commentators drew on Syriac commentaries, what sort of materials they borrowed from, and how they incorporated the borrowed materials into their own commentaries. This paper aims to take a first step in grappling with these issues.

\section{Methodological Approach}

The concept of "influence" has earned a bad reputation over the last several decades. Some claim that after a scholar has identified the existence of parallels between two texts or cultures, there is no need to call this phenomenon "influence." It is argued that by labeling it as an "influence," the scholar merely substitutes the word "parallel" with the word "influence," without making any significant contribution towards understanding the phenomenon. ${ }^{3}$ In the field of Jewish studies in particular it has been claimed that Jews should not be described

\footnotetext{
1 Sarah Stroumsa, "The Impact of Syriac Tradition on early Judeo Arabic Bible Exegesis", ARAM 3,1-2 (1991), 83-96

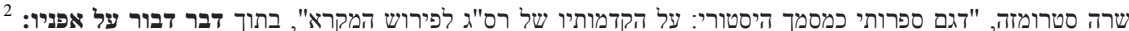

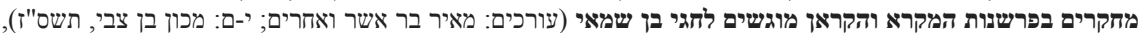
200-199

${ }^{3}$ Eduard Will, "Influence: Note sur un pseudo Concept", dans Hellenica et Judaica: Hommage a Valentin Nikiprowetzky (eds. A Caquot et J. Riado; Paris: Peeters, 1986), 500
} 
as being influenced by their non-Jewish neighbors, but should instead be described as being part of the surrounding culture. In this light it is the difference between Jews and their neighbors that demands explanation, rather than the similarities. ${ }^{4}$ However, the case of Syriac Bible commentaries and Judeo Arabic commentaries is different, given that these are two separate corpuses divided not only by religion and language, but also by time. In Syriac literature, biblical commentaries were a fully developed genre by the ninth century $\mathrm{CE}$, relying on a tradition that spanned centuries. Judeo Arabic biblical commentaries, on the other hand, only first emerged in the tenth century CE. If one discovers parallels between Syriac commentators and Judeo Arabic commentators, and can rule out any other explanation for this parallel and establish that a certain motif has definitely migrated from early Syriac tradition into Judeo Arabic texts of later times, this phenomenon surely can be called influence, in the sense that Judeo Arabic writers adopted the given motif from Syriac tradition.

Influence does not necessarily imply direct contact. A writer may quote a text which borrowed from an earlier text, so that the writer is actually quoting the earlier text without even knowing it. In this way, it is possible that a Judeo Arabic writer could borrow from an earlier Judeo Arabic writer, without even being aware that this earlier writer borrowed from Syriac sources. Only by assembling several cases of Syriac influence, comparing them, and analyzing them, can we attempt to determine how exactly this influence transpired.

The first obstacle in examining the Syriac influence on Judeo Arabic literature is that Syriac literature shares many motifs with the Jewish Midrash, either as a result of direct contact between Jews and Syriac Christians, or as a result of Syriac writers relying on earlier Christian sources that were close to Jewish tradition. ${ }^{5}$ Even Syriac writers engaged in polemics against the Jews relied on Jewish tradition. ${ }^{6}$ These findings hold true not only for early Syriac literature, but for Syriac literature of the eleventh century CE and later as well. ${ }^{7}$ It is often difficult to distinguish whether a Judeo Arabic writer borrowed a specific motif from Syriac sources, or from the Midrash. In most cases, if a motif in Judeo Arabic literature can be traced to both Syriac literature and the Midrash, it is safer to assume a Jewish source. Therefore, before examining Syriac influence on Judeo Arabic commentators, it is necessary to compare the Syriac commentaries and the Midrash.

\footnotetext{
${ }^{4}$ Michael L. Stalow, "Beyond Influence: Toward a New Historiographic Paradigm", in Jewish Literatures and Cultures: Context and Intertext (eds. Amita Norwich and Yaron Eliav; Brown Judaic studies 349; Providence: Brown University, 2008), 46

${ }^{5}$ Sergey Minov, Syriac Christian Identity in late Sasanian Mesopotamia: The Cave of Treasures in Context (Ph.D. Dissertation), The Hebrew University of Jerusalem 2013, 95. Also: A. Toepel, Die Adam- und Seth-Legenden im syrischen Buch der Schatzhöhle. Eine quellenkritische Untersuchung (Corpus Scriptorum Christianorum Orientalium 618; Louvain: Peeters, 2006), 243-244

6 Minov, Syriac Christian Identity, 88. Also: Elena Narinskaya, Ephrem a "Jewish" Sage (Studia Traditionalis Theologia 7; Tournhout: Brepols, 2010), 16-23

7 Sebastian Brock, "Jewish Traditions in Syriac Sources", Journal of Jewish Studies 30, 2 (1979), $212-232$
} 
The Midrash is a literary genre that evolved over hundreds of years, and dating the various texts of the Midrash is problematic and at times impossible. However, most scholars agree that some collections of Midrash (e.g. Bereshit Rabba and the sections of Midrash that are integrated in the Talmud) were already in circulation (not necessarily in their present form) by the beginning of the seventh century CE, before the rise of Islam. Other collections of Midrash (e.g. Pirqe de-Rabbi Eliezer and Tanchuma) were likely edited after the rise of Islam, but were already in circulation by the tenth century $\mathrm{CE}$. These later collections were therefore generally more susceptible to Islamic and Christian influence. ${ }^{8}$ All mentions of the Midrash in the present research refer to the sections of Midrash written before the rise of Islam unless otherwise stated. Later collections will only be discussed if they were already in circulation by the tenth century CE, and Judeo Arabic writers could have used them. Midrash collections of European origin and collections edited after the tenth century CE will not be referenced in this research.

Another factor that should be taken into account is the influence of Islam. Islamic literature both borrowed from and exerted influence on Judaism and Christianity, often leaving uncertainty regarding the direction of influence. For this reason, the current research focuses on biblical stories that are not mentioned in the Quran. The current research also examines "The Tales of the Prophets" (Qișaș al-Anbiya') from Islamic literature, in order to look for a possible Islamic influence on Judeo Arabic commentaries.

Even after having eliminated the possibility of Jewish and Islamic sources in motifs found in Syriac commentaries, this elimination does not suffice in order to safely assume that when these same motifs appear in Judeo Arabic commentaries it is due to influence from the Syriac literature. A motif can appear independently in both traditions. However, when dealing with biblical commentaries, there are two criteria which make the motif less likely to appear twice independently. Firstly, when the motif is very far removed from the literal sense of the scriptures it is unlikely to appear twice separately. Secondly, when this motif constitutes a major break from the commentator's tradition, and the commentator presents it without stressing its innovation or trying to defend his reading against ancient tradition, there are grounds to argue that the motif was not arrived at independently. Therefore, when a Judeo Arabic commentator presents a motif that is far removed from the literal meaning of the Bible, and likewise is divergent from the traditional Jewish interpretation as presented in the Midrash, and furthermore he does so without presenting the motif as an innovation, it is safe to assume that he is likely relying on an alternative tradition-in some cases on a Syriac tradition.

The current study focuses in on three Judeo Arabic commentaries on the book of Genesis. The first is that of Qirqisani, who lived in the middle of the tenth century CE; the second is that of Yefet b. 'Eli, which dates from the end of

\footnotetext{
${ }^{8}$ Regarding the various collections of Midrash and their dating, see: G. Stemberger and M. Bockmuehl, Introduction to the Talmud and Midrash (Edinburgh: Fortress, 1996), 233-359. Also: ענת רייזל מכוגרו מבוא למדרשים (אלון שבות: מכללת הרצוג, תשע"א).
} 
the tenth century CE; and the third is that of Yeshu'ah b. Yehuda, who lived in the eleventh century CE. ${ }^{9}$ These three are compared with the Syriac Bible commentaries of Ephrem (fourth century CE) and Ishodad (ninth century CE), and with the collection of Syriac biblical legends known as the "Cave of Treasures" (approximately sixth century CE). The current research also consults the anonymous commentary from the Diyar Bakir Collection (likely eighth century CE), as well as other Syriac sources when available. ${ }^{10}$ This research intends to explore the differences between the manner in which the Midrash and the Syriac commentators deal with specific biblical stories, and to show that the Judeo Arabic commentators adopted the opinion of the Syriac commentators rather than that of the Midrash. The manner in which Judeo Arabic commentators utilized the materials they borrowed from Syriac tradition will also be analyzed. The examination will begin with the most obvious cases of Syriac influence, and move on to cases where the Syriac influence is less obvious.

\section{The Sons of God (Genesis 6:1-4)}

In Syriac tradition, the "sons of God" mentioned in Genesis 6 are identified with the descendants of Seth, while the "daughters of Adam," whom the sons of God marry, are identified with the descendants of Cain. This interpretation plays an important role in the narrative of the "Cave of Treasure," 11 and it was adopted by the commentators Ephrem and Ishodad. ${ }^{12}$ It is almost never mentioned in the Midrash; only one Midrash - the later (probably eighth century CE) Midrash Pirqe de-Rabbi Eliezer-hints at this interpretation. Chapter 22 of that Midrash describes acts of sin that the sons of God committed with the female descendants

\footnotetext{
${ }^{9}$ These three commentators (their commentaries are as yet unpublished) are Karaites. Commentaries on Genesis in Judeo Arabic were also written by Rabbinical Jews, e.g. the commentary of Saadia Gaon which was later completed by R. Shmuel b. Hofni, but these commentaries were preserved only partially. The commentaries of these two Rabbinical authors on some of the stories examined in the current research have not survived, and the parts that did survive bear no traces of Syriac influence. This, of course, may be purely incidental.

${ }^{10}$ For a survey of the Syriac commentaries, see: L. Van Rompay, "The Development of Biblical Interpretation in the Syriac Churches of the Middle Ages", in Hebrew Bible / Old Testament: The History of its Interpretation 1/2 (ed. Magne Saebo; Göttingen : Vandenhoeck and Ruprecht, 2000), 559-577.

${ }^{11}$ Su Min Ri (ed.), La caverne des tresors: Les deux recensions Syriaques (Corpus Scriptorum Christianorum Orientalium 486; Louvain: Imperimerie Orientaliste, 1987), 80-97, Ch. 11-13 . Cain's descendants and their wickedness are also mentioned in Islamic sources, which likely rely on the "Cave of Treasures," but Islamic sources do not directly identify them with the story of the "sons of God." See: Kisai, Die Prophetenlegenden des Muhammed ben 'Abdallah al-Kisai (ed. Isaac Eisenberg; Leiden: Brill, 1902), 82.

12 Ephraem, Sancti Ephraem Syri in Genesim et Exodum commentarii (ed. R.M. Tonneau; Corpus Scriptorum Christianorum Orientalium 152; Louvain: Imperimerie Orientaliste, 1955), section 6. For an English translation of the commentary, see: St. Ephrem, Selected Prose Works (ed. E. Mathews and J. Amar; The Fathers of the Church 91; Washington: The Catholic University of America Press, 1994), 67-213. For Ishodad, see: Isodad, Commentaire d'Isodad de Merv sur l'Ancien Testaent: I Genese (ed. J.M. Vosté et C. Van der Eynde; Corpus Scriptorum Christianorum Orientalium 126; Louvain: Imperimerie Orientaliste, 1955), 112.
} 
of Cain. However, according to Pirqe de-Rabbi Eliezer, the sons of God were not descendants of Seth but rather fallen angels. This interpretation of the sons of God as fallen angels originates in the Jewish literature of the Second Temple period, and in particular in the book of Enoch. The Syriac commentators were familiar with this interpretation, but appear to have rejected it. ${ }^{13}$ Ishodad explicitly wrote that the sons of God cannot possibly be angels, since angels have no desire for women. ${ }^{14}$ In Rabbinic sources, the term "sons of God" is usually interpreted as referring to the sons of the judges, or the sons of the great ones, ${ }^{15}$ which seems to imply that they were human and constituted an elite group within the society-but these sources fall short of identifying who exactly they were.

The Judeo Arabic commentator Yefet interprets these verses as follows:

"The sons of God saw" (Genesis 6:2). This refers to the sons of Seth and Enos and the generations which came afterwards. When he says "the daughters of Adam" he refers to the descendants of Cain, because Seth is the exalted and favorite son, like Isaac and Jacob, while Cain and his descendants are like Ishmael and the sons of Keturah and Esau, and they are called "Adam" [descendants of Adam] as a generic name. The sons of God have a name by which they are known as a sign of them being noble [...] and for this he has named them God, because of them being noble, and the other human beings, the common folk, he has named Adam. ${ }^{16}$

It would appear to be clear that Yefet has adopted the Syriac interpretations of these verses, an interpretation that is not supported by the literal sense of the Bible and goes against early Jewish tradition. Yefet also adds details which have parallels in Syriac tradition, such as his mention that the descendants of Cain had many girls and only few boys as divine punishment for their sins, and that the large number of girls led to an increase in adultery. ${ }^{17} \mathrm{He}$ likewise mentions that the descendants of Enos could pick and choose any of the female descendants of Cain they pleased, and could also take possession of the property of Cain's de-

\footnotetext{
13 This tradition was adopted by some Islamic sources, which speak of the fallen angels Harut and Marut, or 'Aza and 'Azael. See: Abu Isḥāq al-Nišābūrī al-Ta'labī, Qiṣāṣ al-Anbiya al-Musamma 'Arāis al-Majālis (Aleppo: Dār al-Islām, 1900), 44.

14 Isodad, Commentaire, 111.

15 Sons of Judges : Bereshit Rabba, sec. 26. See also Onqelos (and the later translation, Pseudo Jonathan): "the sons of the great ones" [בני רברביא]. For a survey of the Jewish sources on this subject and Christian parallels, see: Philip Alexander, "The Targumim and the Early Exegesis of Sons of God in Genesis 6", Journal of Jewish Studies 23 (1972), 60-71. Also: A. Van Der Kooij, "Peshitta Genesis 6: Sons of God - Angles or Judges", Journal of Northwest Semitic Languages 23 (1997), 4447.

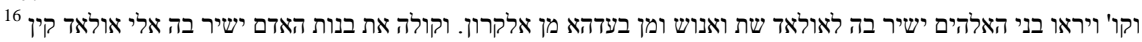

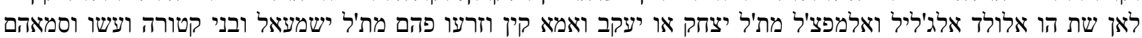

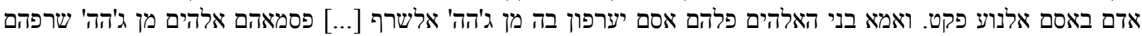
Manuscript: Paris Bibliotheque National Heb. 277, F 4296 in the Institute of Manuscripts near the Jewish National Library, 155a-155b

ואלקול אלאכ'ר פי ובנות יולדו להם כאן ד'לך מן כת'רה' ד'נובהם יקלון אלבנים ויכת'רו אלבנות וענד כת'רה' אלבנות 17

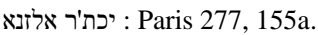


scendants thanks to their exalted status. ${ }^{18}$ The shortage of boys among the descendants of Cain is mentioned by Ephrem and Ishodad; ${ }^{19}$ Ephrem notes that the descendants of Enos could select from the female descendants of Cain, and could likewise take control of the male descendants' property. ${ }^{20}$

In addition to this explanation on the identity of the sons of God, Yefet mentions two others. The first is that they were the sons of judges and rulers, and that corruption in society began in the higher social circles before spreading downwards. ${ }^{21}$ This is essentially the same as the explanation provided by the Jewish Midrash. Yefet does not reject this explanation, but presents it as the opinion of another commentator, subtly implying that he did not agree with it. As for the second explanation mentioned by Yefet, according to which the sons of God were angels, the commentator clearly considers it to be so absurd that there is no need to disprove it. ${ }^{22}$

Qirqasani and Yeshu'ah do not concur with Yefet's view of this matter. Qirqasani, in his short commentary on Genesis, writes: “The sons of God' means the sons of the nobles and kings and leaders. ${ }^{23}$ Like Ishodad, Qirqisani on theological grounds rejects the possibility that the sons of God were angels, but his arguments are more elaborate and influenced by the style of Islamic theology (Kalam). He reasons that the angels, as sublime creatures, are incapable of disobeying God, and as bodiless creatures they cannot father children. As he says: "Those who say that they are angles are clearly wrong. Isn't it strange that the angels, who are close [to God], and whom God placed at the highest rank, would disobey God? [...] and what can be stranger than saying that angels, who are spirits and bodiless beings, father children?" ${ }^{24}$ Yet, Qirqasani seems to recognize that his explanation is far from being complete. If the sons of God are the sons of nobles, in what way exactly was their pedigree more distinguished than that of other human beings, especially at that early period of history in which everyone was nearly a direct descendant of Adam? As Qirqasani himself writes:

If someone is to ask in regard of the noblemen which are the sons of God: Who are they and what is this pedigree that distinguishes them? We will tell him that there are many kinds of pedigree, and the most distinguished among them is the exalted rank of knowledge and piety, and [the Bible] tells us that

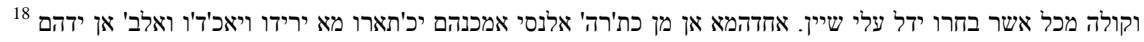

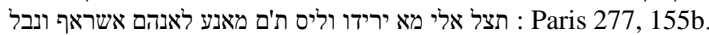

${ }^{19}$ Ephraem, Genesim, sec. 6:2. Isodad, Commentaire, 112.

${ }^{20}$ Ephraem, Genesim, sec 6:5

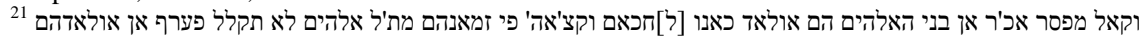
: Paris 277, 155b.

22 פאמא מן פסר בני האלהים מלאיכה' פליס אשתגל באלרד עליהם אד' קולהם פי גאיה' מא יכון מן אלבעדו באלפוד : Paris 277, $155 \mathrm{~b}$

23 Manuscript: SP RNL EVR ARAB I 1366, F54732 in Jewish National Library, 50a.

פאמא קול מן זעם אנהם מלאיכה' פאנה קול בין אלכ'טא אד' כאן עג'ב אן אלמלאיכה' אלמקרבין אלדז'ין כ'צהם אללה

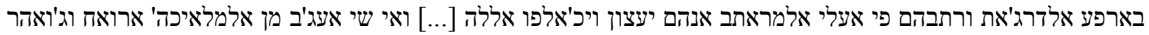
מג'רדה ת'ם יזעם אנהם אנסלו נסל ארו ארל : SP RNL EVR ARAB I 1366, 50a-b.
} 
illness (i.e., corruption) had spread among human beings to the point that it has spread to the men of distinction, who are the men of knowledge and piety, and they have started to sin, and what is worse, they have started to marry the daughters of the lower class, which means the infidels. ${ }^{25}$

Qirqisani raises the question, but the answer he supplies is far from satisfying. Can knowledge really be considered a pedigree? If these two groups were divided along family lines as the sons of God on one side and the sons of Adam on the other, can knowledge really be the dividing factor? The proposed solution is so tenuous that it causes the reader to wonder: Why did Qirqisani even raise the question if he could only counter it with such a poor solution? One possible explanation is that Qirqisani was keenly aware of the existence of an explanation that would solve the problem perfectly; namely, that the pedigree of the sons of God was different from that of other human beings, because they were descendants of Seth while the others were descendants of Cain. Despite this, Qirqisani wanted to prove that he also had a solution for the question of the different pedigree of these two groups. However, Qirqisani makes no mention of the Syriac explanation, leaving us only able to speculate about whether or not he was familiar with it.

Yeshu'ah was also of the opinion that the sons of God were members of a higher class of society, and his writings give no hint that he was aware of the explanation according to which they were the descendants of Enos. He writes: "This abomination [i.e. the sins committed by the sons of God] was not the portion of the lower class [only] but rather of the elite, who acted as a role model for the people, for better or worse.",26

\section{Nimrod (Genesis 10:8-12)}

The attitude of Syriac literature regarding Nimrod is somewhat complicated. According to the Cave of Treasures, he was an evil king who was the first idol worshipper, and the first to worship fire. ${ }^{27}$ This opinion of Nimrod is shared by both the Jewish Midrash, which tells us that he was a fire worshiper who tried to throw Abraham into a fire, ${ }^{28}$ and by Islamic tradition. ${ }^{29}$ In Syriac biblical commentaries, however, Nimrod is treated as a positive figure. Ephrem wrote that Nimrod fought with different families of the human race according to God's will, and forced them to move to the places where God desired for them to be. He add-

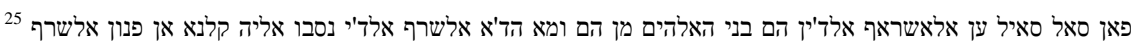

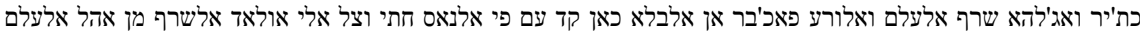
SP RNL EVR ARAB I 1366, 50b.

${ }^{26}$ : לם יכן הד'א אלקביח מן אלאדואן בל מן אלכ'ואץ אלד'י יקע אלתאסי בהם פי אלכ'יר ופי גירזירה RNL EVR ARAB I 2015, F55110 in Jewish National Library, 72b.

${ }^{27} \mathrm{Ri}$, Caverne, 208-209, Ch. 27:1

Nimrod told him: I worship fire, so I will throw you in it"; Bereshit Rabba, sec. 38.

${ }^{29}$ Kisai, Prophetenlegenden, 124.
} 
ed that the phrase "a hunting champion like Nimrod" (Genesis 10:9) was a blessing used by men to bless kings and rulers who fought and won battles for God. ${ }^{30}$ Ishodad repeats these explanations and adds that the words of the Bible: "Therefore people say: A hunting champion like Nimrod" (Genesis 10:9) were a comment made by Moses. According to Ishodad, in Moses' time the phrase "a hunting champion like Nimrod" was a common blessing: "The words 'a Hunting Champion like Nimrod etc.' were said by Moses, because in his time it was used as a common phrase when men were blessing each other." ${ }^{\prime 31}$ The Syriac anonymous commentary from the Diyar Bakir collection states that the phrase "a hunting champion like Nimrod" was a blessing, but does not indicate that it was a comment made by Moses. ${ }^{32}$ This commentary was likely written at the end of the eighth century CE, and it is reasonable to posit that it was one of Ishodad's sources. ${ }^{33}$ The anonymous commentary from the Mingama collection gives the same opinion that the phrase was a blessing. ${ }^{34}$

Such a positive attitude towards Nimrod is rare in Jewish sources, and is only hinted at in one source that was edited in the early Islamic period. That source is Pseudo Jonathan's Aramaic translation of Genesis 10:11, which relates that Nimrod refused to take part in the building of the tower of Babel and in reward for this action God gave him control over four cities. However, only a few verses earlier in Genesis 10:9, Pseudo Jonathan refers to Nimrod as a man who had rebelled against God.

Yefet considers Nimrod to be a positive figure. He writes that Nimrod was a clever hunter, and that according to some scholars he earned the rank of being considered as though he were one of Ham's sons even though he was only his grandson, thanks to his distinguished qualities. ${ }^{35}$ Yefet also comments on the phrase: "Therefore people say: A hunting champion like Nimrod" and gives a similar interpretation to that of Ishodad:

The phrase "therefore people say"- these are the words of our lord Moses, saying that every hunting champion or clever hunter is compared to Nimrod, and people say: this man is like Nimrod, and this proves that no man after him ever surpassed him in hunting - no one who would have become a model for comparison [instead of Nimrod]. ${ }^{36}$

\footnotetext{
${ }^{30}$ Ephraem, Genesim, Sec. 8:1

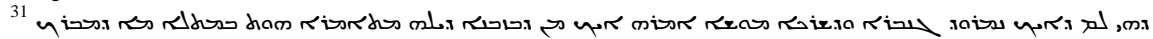
minul ram: Isodad, Commentaire, 134.

32 Lucas Van Rompay (ed.), Le Commentaire sur Genese - 9:32 du Manuscript (olim) Diyar Bakir 22 (Corpus Scriptorum Christianorum Orientalium 483-484; Louvain: Imperimerie Orientaliste, 1986), I 67

${ }^{33}$ Van Rompay, Commetaire sur Genese, II 52

34 Abraham Levene (ed.), The Early Syriac Fathers on Genesis (Tailor's Foreign Press: London, 1951), 52, 85

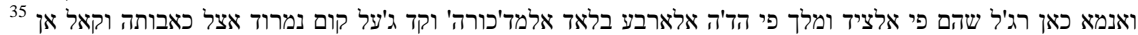

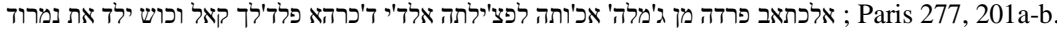

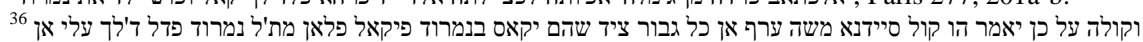

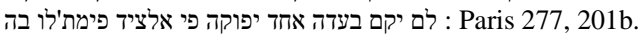


Yefet's comment and Ishodad's words are similar not only in content, but also in phrasing. It should be noted that the last part of Yefet's comment: "have become a model for comparison," and Ishodad's words: "used as a common phrase," are both based on the same Semitic stem "m.t.l." (used both in Syriac and Arabic), and therefore one could easily be a translation (or a mistranslation) of the other. ${ }^{37}$

Yeshu'ah shared the opinion that Nimrod was an expert hunter. He attributes the phrase: "Therefore people say: A hunting champion like Nimrod," to the prophet (i.e. Moses), arguing that Nimrod was an expert hunter and that the phrase: "a hunting champion like Nimrod" was a common phrase in Moses' time, for no man in the periods from Nimrod's time until Moses' time was a better hunter than Nimrod. ${ }^{38}$

It seems clear that in their attitude towards Nimrod, Yefet and later Yeshu'ah adopted the position of Syriac commentators, which stands in contradiction to that of the Jewish Midrash. The attribution of the phrase: "Therefore people say: A hunting champion like Nimrod" to Moses is particularly significant. A general positive attitude towards Nimrod and his glorification as a hunting champion both agree with the literal sense of the Bible, so that the Judeo Arabic writers could feasibly have reached that conclusion on their own, without consulting Syriac sources.

However, the Bible makes no mention of Moses or Moses' time period at all in this context. Moreover, Moses' role in writing the Pentateuch is linked to an important issue in Karaite Bible commentaries; namely, the importance of the prophet who serves as a biblical scribe, known as "al-mudawwin." According to Karaite commentators, the mudawwin plays an important role in the codification of the scriptures, and can change the phrasing of the words revealed to him and to other prophets by God by adding his own comments and interpretations - not by his own free will, of course, but rather as part of his prophetic mission. ${ }^{39}$ Ben Shammai and Goldstein, who examined the mudawwin's role, mentioned the Islamic (mainly Shiite) origins of the concept. ${ }^{40}$ As we can see in this reading of the

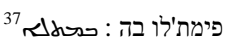

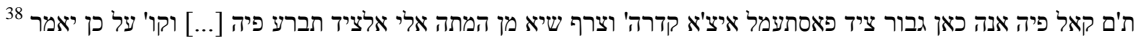

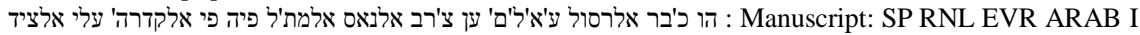
3204, F57467 in Jewish National Library, 55 b.

${ }^{39}$ The mudawwin often remains unidentified. He is usually more of a literary character than an historical figure, and his role is somewhat similar to that of the "narrator" in modern literary theories. However, Moses is usually considered to be the mudawwin of the Pentateuch. For the literary role of the mudawwin see: M. Polliack, "The Voice of the Narrator and the Voice of the Characters in the Bible Commentaries of Yefet b. 'Eli," in Birkat Shalom (eds. C. Cohen et al.; Indiana: Eisenbrauns, 2008), 891-915; M. Polliack, "Karaite Conception of the Biblical Narrator (Mudawwin)," in Encyclopaedia of Midrash (eds. J. Neusner and A.J. Avery-Peck; Leiden: Brill, 2005), I 350-374; M. Zawanowska, "Was Moses the mudawwin of the Torah? The Question of Authorship of the Pentateuch According to Yefet ben "Eli," in Studies in Judaeo-Arabic Culture: Proceedings of the Fourteenth Conference of the Society for Judaeo-Arabic Studies (eds. H. Ben-Shammai et al.; Tel Aviv: Tel Aviv University, 2014), 7-35.

${ }^{40}$ Miriam Goldstein, Karaite Exegesis in Medieval Jerusalem: The Judeo Arabic Pentateuch Commentary of Yusuf ibn Nuh and Abu al-Faraj Harun (Texts and Studies in Medieval and Early Modern
} 
Syriac and Judeo Arabic commentaries, this concept was also influenced by Christian theology.

Ishodad several times in his commentary mentions that Moses played an important part in the codification of the Pentateuch - for instance, he writes it was Moses who determined which part of the Pentateuch would be placed at the beginning. Although the book of Exodus was written before the book of Genesis, Moses placed the books according to the order in which Divine Providence runs the world, rather than the order of their composition. ${ }^{41}$ Other Syriac writers from the ninth century CE present similar ideas. Moses Bar Kepha, a younger contemporary of Ishodad, stressed the role of Moses as the author of the Pentateuch. In his commentary on Genesis 3:3, Bar Kepha wrote that sometimes Moses omitted some details when describing the events of the biblical stories, and there is a parallel for this remark in Yefet's commentary. ${ }^{42}$ Isho Bar Nun, in the thirteenth of his questions on the Pentateuch, asks why Moses did not write the names of Kain and Seth's wives. ${ }^{43}$

\section{Noah and Canaan (Genesis 9:20-27)}

The story of Noah and Canaan is interpreted in Syriac literature differently than in the Midrash. Most of the writers of the Midrash assume that the words "saw the nakedness of his father" (Genesis 9:22) are a euphemism for something much more terrible, and that Noah was actually raped or castrated. ${ }^{44}$ The Syriac commentators, however, assume that Noah was only seen naked. ${ }^{45}$ Therefore, they have a hard time explaining why the action was so awful. In the Cave of Treasures, it is said that not only did Ham see his father naked but he also

חגי בן שמאי, "על מדון, עורך ספרי המקרא בפרשנות . Judaism 26; Tubingen: Mohr Siebeck, 2011), 120-123 המקרא הערבית יהודית", בתוך ראשונים ואחרונים: מחקרים בתולדות ישראל מוגשים לאברהם גרוסמן (עורכים: יוסף יוסר

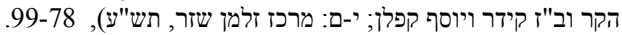

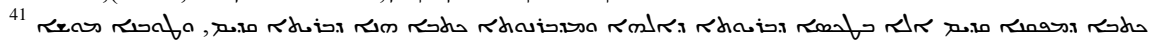

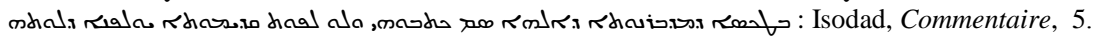

42 Yonatan Moss, "Scholasticism, Exgesis and the Historicization of mosaic Authorship in Moses Bar Kepha's on Paradise," Harvard Theological Review 104 (2011), 338-339. As Moss states, the concept of Mosaic authorship may have some Islamic background, but its utilization in interpreting the scriptures is certainly of Christian origin, since Muslims do not confer a similar role to Muhammad in Quran Commentaries [ibid, 347].

${ }^{43}$ Ernest G. Clarck (ed.), The selected Questions of Isho Bar Nun on the Pentatatuech (Studia Post Biblica 5;Leiden: Brill, 1962), 26

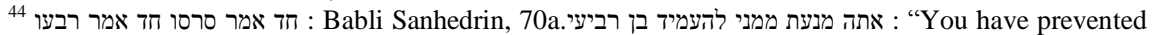
me from having a fourth son": Bereshit Rabba 37:11. For a survey of these rabbinical sources and their relation to the Christian legend about the fourth son of Noah, see: S. Gero, "The Legend of the Fourth Son of Noah," Harvard Theological Review 73 (1980), 322; A. Toepel, "Yonton Revisited", Harvard Theological Review 99 (2006), 235-245. This seems to be the opinion of most Midrshic sources. Some late Midrashic sources, however, are of different opinion: Ham the father of Canaan did not strike [Noah] but only saw [him naked]: [חם אבי כנען לא הכה אלא ראה בלבד] Shemot Rabba 30:5.

${ }^{45}$ Some Islamic sources also say that Noah was only seen naked, but these sources mention details which no Judeo Arabic source mentions, (for example, that a strong wind lifted Noah's clothes), and therefore it is less likely that these Islamic sources influenced Judeo Arabic commentaries. See: Kisai, Prophetenlegenden, 99. 
mocked him. ${ }^{46}$ According to Ishodad, Noah assumed that the house was empty because everyone had gone to work. Ham, however, went back home to look for something and saw his father drunk and naked. Ham did not know what it meant to be drunk, and therefore believed that Noah was sleeping while everyone else was working - a thought that made him very angry. He called his brothers to show them how lazy their father was. In doing so, Ham made three grave errors: he saw his father naked; he failed to cover him; and he told his brothers. ${ }^{47}$ The same can be found in the anonymous commentary from Diyar Bakir. ${ }^{48}$

The Jewish Midrash does not devote much thought to the question of how Noah found out what had been done to him while he was drunk, likely because the writers of the Midrash posited that Noah was raped or castrated, which he could not help but notice. The only Jewish source that deals with this question is Pseudo Jonathan's translation of Genesis 9:24, which states that what happened to Noah was revealed to him in a dream. ${ }^{49}$ The Syriac sources, which maintain that Noah was only seen naked, give the matter more serious attention. In the Cave of Treasures, Noah's wife tells him what Ham had done. ${ }^{50}$ Ephrem says that although Noah was drunk, he was not completely unaware of his surroundings. He may not have noticed that he was naked, but he was nevertheless aware of what Ham had done. ${ }^{51}$ According to Ishodad, Ham's action was revealed to Noah by God in a dream. ${ }^{52}$

Another question which the Syriac writers focused on, while the writers of the Midrash did not, is: Why did Noah allow himself to get drunk? The Syriac writers believed that Noah did not intend to get drunk, but nevertheless he did so anyway. The Cave of Treasures version holds that Noah was unaccustomed to drinking wine, and for this reason he became inebriated quickly. ${ }^{53}$ Ephrem states that Noah's intoxication was not caused by him drinking a large quantity of wine, but rather it was due to the fact that he had not drunk wine for a long time. He did not drink at the time of the flood, and three or four years had elapsed after the flood until the vineyard was able to produce wine. ${ }^{54}$ Ishodad claims that Noah was unaware that wine can cause intoxication, arguing that he was the first man ever to make wine. Moreover, grape juice does not induce drunkenness, and Noah had no way of knowing that in later stages the juice becomes wine and can cause inebriation. ${ }^{55}$

\footnotetext{
${ }^{46} \mathrm{Ri}$, Caverne, 156-157, Ch. 21:1

${ }^{47}$ Isodad, Commentaire, 127

${ }^{48}$ Van Rompay, Commetaire sur Genese, I 63

וידע באשתעות חלמא

${ }^{50} \mathrm{Ri}$, Caverne, 158-159, Ch. 21:6

${ }^{51}$ Ephraem, Genesim, sec. 7:3

${ }^{52}$ Isodad, Commentaire, 128

${ }^{53} \mathrm{Ri}$, Caverne, 157, Ch. 21:2

${ }^{54}$ Ephraem, Genesim, sec. 7:2. This explanation is probably based on Jubilees 7:2, which says that Noah's vineyard produced wine in the fourth year (according to biblical law, Leviticus 19:23-24). Jubilees, however, does not present this as a reason for Noah's drunkenness.

${ }^{55}$ Isodad, Commentaire, 130.
} 
One of the most puzzling aspects of this biblical story, which bothered the Syriac writers and the authors of the Midrash alike, is this: If Ham was the sinner, why was Canaan cursed? One explanation supplied by the Midrash (Bereshit Rabba 37) and mentioned as an option by Ephrem and Ishodad is that it was Canaan who saw Noah naked and told Ham. As a proof of this explanation, Ephrem cites the biblical passage in which Noah "woke up and saw what his small son had done to him" (Genesis 9:24). Ham was not Noah's youngest son; he is always mentioned as the middle son. Therefore, the Bible must mean Canaan, Ham's youngest son. ${ }^{56}$ Another option suggested by Ishodad is that since Ham did not respect his father and caused him grief, his son Canaan was cursed and caused him grief in turn. ${ }^{57}$

Like the Syriac commentators, Qirqisani believes that Noah was only seen naked and nothing more. He says:

Some people say that a sin was committed beyond the act of seeing - that something was actually done, and that the words "he saw" (Genesis 9:22) are equivalent to the words "and he saw her nakedness" (Leviticus 20:17) (i.e. engaged in sexual intercourse). [...] As proof, they cite the words "and he knew what his small son had done to him," which imply that something was actually done beyond mere seeing. Noah saw the results when he woke up, and cursed his son for what he had done. We, however, say that when Noah's son saw him, he did not hide his face and stand aside; on the contrary, he looked with attention, and sinned by looking at what he was not allowed to watch $[\ldots]$ as for him knowing what happened - his two sons may have informed him, or someone else. ${ }^{58}$

Yefet believes that Ham was at fault for having entered Noah's tent with no warning - he should have at least waited until he was sure that Noah was no longer drunk. Like Ishodad, Yefet believes that Ham committed three sins. ${ }^{59}$ Yefet refrains from explicitly enumerating what these three sins are, but he seems to describe them slightly differently than Ishodad: Ham entered his father's tent; he saw him naked; he told his brothers. Yefet's objection to Ham entering Noah's tent without warning may be an adaptation of the story related by Ishodad about Ham returning from work in the middle of the day and surprising Noah in the

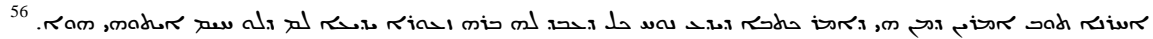
ram Ephraem, Genesim, sec. 7:3.

${ }^{57}$ Isodad, Commentaire, 128.

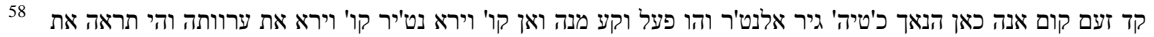

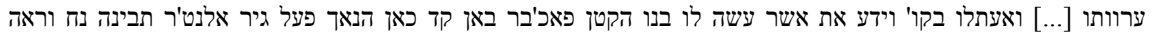

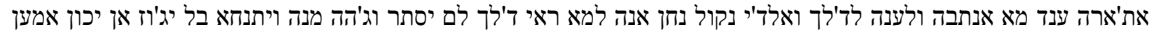

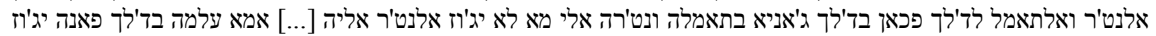

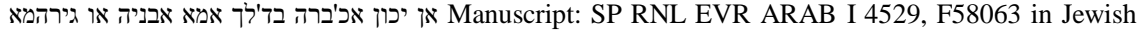
National Library, 17a.

ד'ם לה אנה דכ'ל מצ'רב אלאב גפלה' וקד כאן סבילה לא ידכ'ל אלי מצ'רב אלאב אלא בעד עלמה אן אלאב מסתיקץ' מן 59 'יכל

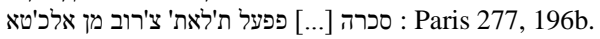


tent. Yefet also reasons that it was likely from God that Noah learned about his son's actions. ${ }^{60}$

Like Yefet, Yeshu'ah also believes that Ham should not have entered Noah's tent without permission, should not have told anyone about what he had seen, and should not have made fun of Noah. ${ }^{61} \mathrm{He}$ also says that Noah probably discovered Ham's actions through divine revelation. ${ }^{62}$

The only act the Bible attributes to Ham is the act of seeing his father's nakedness, meaning that the interpretation adopted by the Judeo Arabic commentators agrees with the literal meaning of the scriptures, and therefore they could have arrived at it on their own without consulting Syriac sources. However, these same commentators clearly struggle with this explanation and are unable to regard the act of seeing as a sin by itself, and as a result they are compelled to aggravate Ham's sin by attributing to him responsibility for other actions which are not mentioned in the Bible at all. Therefore, one cannot claim that the Judeo Arabic commentators chose to adopt their explanation out of a loyalty to the literal sense of the Bible. It is also imperative to recall that their explanation goes against early Jewish tradition as described in the Midrash, according to which Noah was raped or otherwise molested. Qirqasani mentions this tradition, but makes no serious attempt to disprove it. Yefet and Yeshu'a make no mention of it at all. This state of affairs would suggest that the Judeo Arabic commentators did not consider themselves as innovators battling against ancient tradition, but rather as commentators who chose to adopt an equally respected and accepted tradition. Yefet's commentary in particular-mentioning three sins - reveals that the tradition they followed was of Syriac origins.

Judeo Arabic Bible commentators, in a similar fashion to the Syriac writers and in contrast to the sages of the Midrash, proposed various answers to the question of why Noah got drunk. Qirqisani says that according to some scholars, Noah was not aware that wine induces drunkenness. ${ }^{63}$ This is in essence the same answer given by Ishodad. Yefet says that according to the Bible, Noah got drunk in his own tent-which is not problematic, as opposed to if he had gotten drunk in public and disturbed others. Noah was sleeping in his room and posed no nui-

\footnotetext{
${ }^{60}$ : והד'א אלעלם לים בבעיד אן אללה אעלמה : Paris 277, 196b. The Karaite commentators were interested in the question of how Noah knew about Ham's actions for theological reasons: They wanted to avoid the impression that Noah cursed Canaan by mistake (instead of Ham) and God fulfilled his curse, which would make God appear to be unjust. See: M. Polliack and M. Zawanowska, "God would not Give the Land but to the Obedient: Medieval Karaite Responses to the Curse of Canaan", in The Gift of the Land and the Fate of the Canaanites in Jewish Thought (eds. K. Berthelot, J. David and M. Hirshman; Oxford: Oxford University press, 2014), 123.

אלטען עלי מן הג'ם עליה בדון אסתיד'אן כמא יפעל אהל אלאדב ת'ם לא יכפה ד'לך חתי שהר אמרה ללגיר עלי טריק 61 אית אלתנקץ בה : SP RNL EVR ARAB I 3204, 52b.

62 : ויקץ נח קולה וידע יקרב אנה בוחי : SP RNL EVR ARAB I 3204, 52b.

וקד זעם קום אן נח לם יעלם אן אלשראב יפעל ד'לך אלסכר פלד'לך שרב מנה מא שרב : SP RNL EVR ARAB I 4529, 17a.
} 
sance to anyone. It was Ham's fault that he entered Noah's tent without permission, thereby making the matter public. ${ }^{64}$

Yeshu'ah reasons that Noah drank wine because he was happy that God had promised not to destroy the world again in a flood, and he maintains that there is nothing wrong in drinking wine as long as it does not induce you to act foolishly or neglect your obligations. ${ }^{65}$ As for Noah getting drunk, Yeshu'ah suggests two possible explanations. According to one, Noah, unaccustomed as he was to drinking wine, did not realize that the quantity of wine he was imbibing would make him drunk. Noah lived for five hundred years in purity and worshipped God, and for this reason even a small amount of wine was enough to cause him to get drunk. $^{66}$ This explanation is essentially identical to that given by Ephrem. The second explanation is the one given by Yefet: Noah was in his tent, out of sight, and therefore blame shouldn't rest on him but rather on Ham, who entered his tent without warning. ${ }^{67}$ All of these explanations have no support in the literal sense of the Bible, and are unlikely to have appeared in Syriac and Judeo Arabic commentaries independently.

Qirqisani, in dealing with the question of why Canaan was cursed instead of Ham, mentions the possibility that Canaan was the sinner instead of Ham: "Some people say that the one who did the deed was Canaan and not Ham, and as a proof they cite the words 'what his small son did to him,' saying that Ham was not the smallest, but rather the middle son, because in every place [they are mentioned] it is said 'Sem, Ham and Yefet"' (Genesis 9:18) ${ }^{68}$ This argument is mentioned by Ephrem but it is not mentioned in the Midrash, although some writers of the Midrash believed Canaan was the sinner. Qirqisani does not rule out this explanation, but he believes it is only a partial explanation which should be integrated with other explanations that he proposes. He believes that Canaan was the first one to commit a sin by seeing Noah naked and for that he was cursed, and later he told his father Ham about it, after which Ham came in and saw his father naked as well. ${ }^{69}$

Yefet says that Ham sinned, and therefore deserved to grieve over the punishment of his son. ${ }^{70}$ Yeshu'ah likewise says that sometimes a father is punished

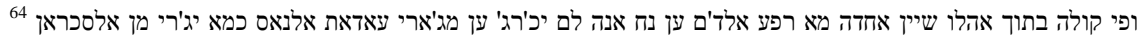

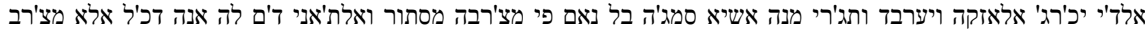

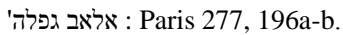

ולעלה אמען פי אלשרב סרורא בעמארה' אלעאלם ובמא תקדם מן ועדה סבחאנה באנה לא יכ'רבה פאת'ר מעה סכרא ולא

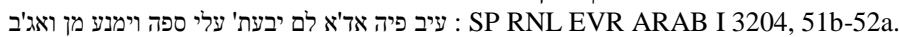

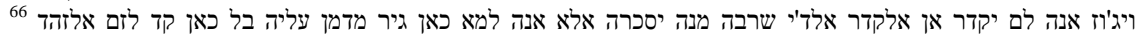
SP RNL EVR ARAB I 3204, 52a.

וקו' בתוך אהלו בין בה אנה לם יכן ט'אהרא פי אלטריק פכאן יוג'ה אליה אלטען בל אלטען עלי מן הג'ם עליה פי מוצ'עה 67 . בדון אסתיד'אן : SP RNL EVR ARAB I 3204, 52b.

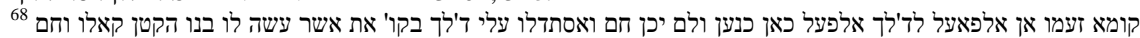

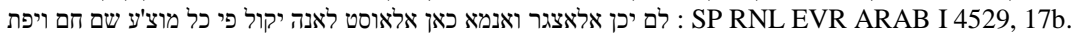

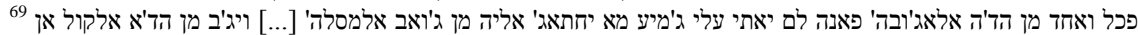

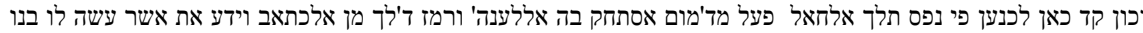

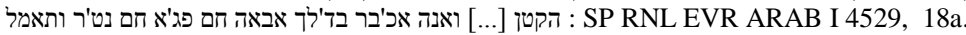

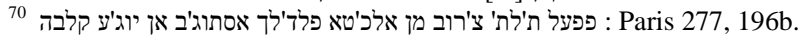


by disasters afflicted on his son, as the son's punishment causes the father's heart to grieve. ${ }^{71}$ This is similar to the explanation mentioned by Ishodad-that Ham caused his father grief, and was therefore punished with grief caused by seeing his own son cursed.

The similarities between Syriac interpretations and Judeo Arabic interpretations in the story of Noah's drunkenness are not as obvious as those found in the stories of the sons of God and of Nimrod, but it stands to reason that there are simply too many of them to disregard them all as coincidences.

\section{Judah and Tamar (Genesis 38)}

According to the Jewish Midrash, Judah decided to forbid Tamar from marrying his third son because the death of his two sons while they were married to her appeared to him to be a bad omen. ${ }^{72}$ The Midrash never mentions any reason to suspect that sins on the part of Tamar had caused the death of her husbands. Ephrem, however, writes that Tamar herself believed that this was so- that her sins had caused the death of her first two husbands, and this was the reason that she left Judah's home until the third son came of age to marry. According to Ephrem, Judah himself believed that Tamar was an idol worshiper and that her sins had caused the death of his two sons, and it was for this reason that he refused to let her marry his youngest son. Only after Tamar becomes pregnant from Judah and informs him that he is the father without making the matter public does Judah understand that his sons died because of their sins, and not due to Tamar's sins. ${ }^{73}$ The anonymous commentary from Diyar Bakir likewise states that Judah believed that Tamar's sins caused the death of his sons. ${ }^{74}$

Qirqisani embraces the same line of thinking, but he takes it even further. $\mathrm{He}$ says that when Judah's understood that Tamar was pregnant with his child it only strengthened his negative view of her. According to Qirqisani, Judah said: "I knew she played tricks on men because of the death of my two sons - for I knew she was the cause of their deaths, and this is why I did not marry her to my third son, so that his fate would not be like that of the first two." ${ }^{, 75}$ Moreover, Qirqisani asserts that Judah was not entirely mistaken when he attributed the death of his two sons to Tamar's sins. He says:

\footnotetext{
71 : וקד יג'וז אן יעאקב אלאב במא יג'רי עלי אלאבן ויולם קלבה באן יערף בה מן חאלה : SP RNL EVR ARAB I 3204, $52 \mathrm{~b}$.

72 "Divination is forbidden, but seeing an omen is not"; Bereshit Rabba, sec. 85:7. For details on the character of Tamar in the Midrash, see: Ester Blachman, The Transformation of Tamar (Genesis 38) in the History of Jewish Interpretation (Leuven: Peeters, 2013), 159-179.

${ }^{73}$ Ephraem, Genesim, sec. 34:6. For details on Ephrem's interpretation on the story of Tamar and its Jewish parallels, see: T. Kronholm, "Holy Adultery: The interpretation of the Story of Tamar in the Genuine Hymns of Ephrem," Orientalia Suecana 40 (1991), 149-163.

${ }^{74}$ Van Rompay, Commetaire sur Genese, I 112

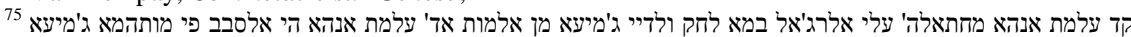
פלד'לך לם אזוג'הא באלת'אלת' לילא יחל בה מא חאל באלאת'נין : Manuscript: SP RNL EVR ARAB I 3195, F60981 in Jewish National Library, 19a.
} 
One might ask: Why did he [Judah] say that she [Tamar] caused the death of his two sons, while the Bible says of Er that he "was wicked in the Lord's sight," (Genesis 38:7) and about Onan that "he spilled his seed on the ground" (Genesis 38:9)? [...] The answer to this question is twofold. First, he was not aware of his son's sins and mistakenly believed Tamar to be the cause. Another possibility is that she was indeed the cause of their deaths; he believed that was the case, but when she tricked him, he became sure of it. In other words, Tamar was the cause of Er's wickedness by seducing him or helping him, although the Bible does not explicitly say so. ${ }^{76}$

Qirqisani's explanations are not supported by the literal sense of the Bible, and they go against everything the writers of the Midrash had to say about Tamar's innocence and chastity. ${ }^{77}$ It would seem that Qirqisani followed the Syriac tradition by casting doubt on Tamar's character, but in his enthusiasm to exonerate Judah and place all of the blame on Tamar, he went much further than the Syriac writers had ever dreamed.

The sages of the Midrash were divided over the question of Judah and Tamar's relationship after she gave birth to her twins. Some sages believed that Judah did not have intercourse with Tamar after the first time, while others believed that their sexual relationship continued. ${ }^{78}$ Ephrem chose a middle route, or rather he accepted the former opinion that they did not continue to have intercourse, albeit with a small reservation. Ephrem mentions that after Judah found out that Tamar was pregnant with his sons he never slept with her again, for she was his former daughter-in-law. Nevertheless, she lived in his home because she was the mother of his sons. ${ }^{79}$

Yefet makes a similar remark: "The Bible tells us that he never slept with her again, because she was forbidden to him, and if she had not been forbidden to him he would not have been permitted to not sleep with her, since she had become the mother of his sons, [a status she would keep] until death." ${ }^{80}$ In other words, Judah and Tamar were bound by a relationship resembling marriage since she was the mother of his sons, and Judah should therefore have had intercourse with her. However, he could not do so because as the widow of his sons she was forbidden to him. The theory of Tamar and Judah's ongoing relationship (even

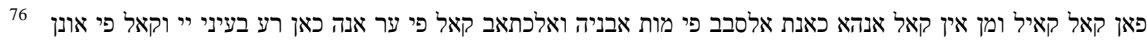

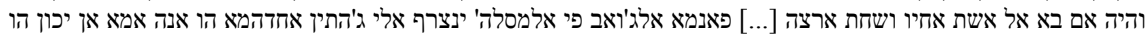

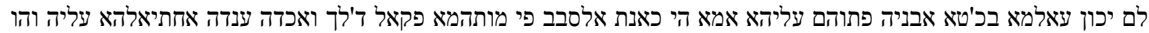

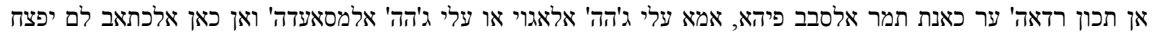
בד'לך : SP RNL EVR ARAB I 3195, 19b-20a.

Stephan Reif, "Early Rabbinic Exegesis on Genesis 38," in The Exegetical Encounter between Jews and Christians in Late Antiquity (eds. E. Grypeuo and H. Spurling; Jewish and Christian Perspectives 18; Leiden: Brill, 2009), 231-232

${ }^{78}$ Sifre Beha'alotcha 8; Babli Sota 10b. See: Reif, Early Rabbinic Exegesis, 230.

${ }^{79}$ Ephraem, Genesim, sec. 34:6

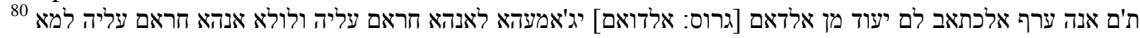

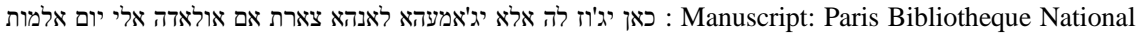
heb. 278, F4326 in Jewish National Library, 185b.
} 
non-sexual) after the birth of her sons is not supported by the literal sense of the Bible, and Yefet's explanation does not agree with either of the opinions presented in the Midrash. Therefore, it likely relies on Syriac tradition.

\section{Summary and Conclusions}

To draw conclusions based on such a small amount of material is a risky endeavor, but certain conclusions do seem to present themselves, and they may be proved or disproved by further study.

The first issue one should consider when dealing with the reception of Syriac materials in Judeo Arabic literature is the means of communication. Did Judeo Arabic writers read Syriac literature or Arabic adaptations of it, or did they rely on oral discussions with Christians? Oral discussions surely existed, as the famous story of R. Hai Gaon consulting with the Syriac head priest about the meaning of a verse from the Psalms attests. ${ }^{81}$ However, some remarks made by Judeo Arabic commentators, and especially Yefet's remark about the description of Nimrod being an editorial comment by Moses, can almost be seen as a direct translation of the Syriac source into Arabic. The interpretation is too close to its Syriac parallel, not only in content but also in phrasing, to assume that it was transmitted orally. ${ }^{82}$

Another question to be pondered is what type of information Jews were looking to receive from the Syriacs, and what kind of Syriac literature they were interested in. The influence of Ephrem and Ishodad on Judeo Arabic commentators is quite significant, whereas the influence of the Cave of Treasures on Judeo Arabic commentators is minimal, if not non-existent. It would seem as if the Jews considered Syriac biblical commentaries to be a serious source for understanding the Bible, whereas they approached the Cave of Treasures as nothing more than a collection of legends. This hypothesis also supports the theory that Judeo Arabic writers relied on written Syriac materials rather than oral discussions, a turn of events that would explain why certain Syriac genres were used while others were ignored.

The difference between the three Judeo Arabic writers discussed above regarding their use of Syriac materials should also be noted. Yefet seems to be the most eager to adopt the ideas of Syriac commentators, which he occasionally presents as if they were his own. Qirqisani uses Syriac materials extensively, but with much more reservations. In some cases he mentions the explanations of Syriac commentators but later rules them out, while in other cases he adopts Syriac explanations although only after considerable changes. As for Yeshu'ah, it would seem that most of the Syriac material he used was borrowed from Qirqisani and Yefet. Only rarely do we find in his writings Syriac materials that do not originate with those writers, with one example being his explanation of Noah's drunken-

\footnotetext{
יוסף בן עקנין, התגלות הסודות והופעת המאורות: פירוש שיר השירים לר' יוסף בן יהודה בן יעקב אבן עקנין 81 יעירים

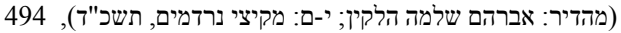

${ }^{82}$ The influence of Syriac literary style on R. Saadia Gaon's commentaries, mentioned by Stroumsa (סטרומזה, דגם ספרותי, also points to transmission of written materials rather than oral discussions.
} 
ness, and even in these cases he most likely drew on other Judeo Arabic commentaries rather than Syriac sources. ${ }^{83}$

The last question, and probably the most complex, is that of language. It is natural to assume that Judeo Arabic biblical commentators used Arabic adaptations of Syriac commentaries rather than the Syriac original. Qirqisani used Daud b. Marwan's Judeo Arabic commentary that was based on Syriac commentaries, and there were probably Christian Arabic adaptations available as well. The commentary of 'Abd Allah b. Tayyib on Genesis appeared in the eleventh century $\mathrm{CE}$, and was essentially an Arabic adaptation of Ishodad's commentary. ${ }^{84}$ It is entirely within the realm of possibility that such adaptations already existed in the tenth century CE.

However, one has to consider the possibility that Judeo Arabic writers could read Syriac. In the tenth century CE Jews in Mesopotamia, and probably in the Holy Land as well, could read and write Aramaic fairly well, as is shown by the literature of the Geonim, large portions of which are written in Aramaic. ${ }^{85}$ The different orthography of Jewish Aramaic and Syriac was likely not too great an obstacle. During the eleventh century CE knowledge of Aramaic gradually declined ${ }^{86}$ This may be the reason that Yeshu'ah took most of his Syriac material from his Judeo Arabic predecessors, as he could no longer understand the Syriac original.

\footnotetext{
${ }^{83}$ Yeshu'ah borrowed a great deal of material from previous Judeo Arabic commentators. See:

חגי בן שמאי, "ישועה בן יהודה: לדמותו של חכם קראי ירושלמי במאה האחת עשרה", פעמים 32 (תשמ"ז), 9-6.

${ }^{84}$ Ibn aț-Ṭaiyib , Commentaire sur la Genèse (ed. Joannes C. J. Sanders; Corpus Scriptorum Christianorum Orientalium 274-275; Louvain: Imperimerie Orientaliste, 1967).

${ }^{85}$ Karaites did not write in Aramaic, but that does not mean they could not read it. Qirqisani had lived in Baghdad, an important center for Rabbinical and Syriac intellectual activity, and he was well versed in their thought, as we can see from his book Kitab al-Anwar, so it is reasonable to assume he knew Aramaic. As for Yefet, his commentary on the Aramaic sections of the book of Daniel shows he had a good grasp of biblical Aramaic, and some knowledge of the Aramaic translation on the Bible. See: Jephet ibn Ali the Karaite, A Commentary on the Book of Daniel (ed. D. S. Margoliouth; Oxford: Oxford University Press, 1889), 18, 67.

${ }^{86}$ Joshua Blau, The Emergence and Linguistic Background of Judeo Arabic (Scripta Judaica 5; London: Oxford University Press, 1965), 20.
} 